\title{
UKŁAD WYLOTOWY TYPU OSIOWEGO DYFUZORA LOPATKOWEGO SPRĘŻARKI PROMIENIOWEJ
}

\begin{abstract}
Osiowy dyfuzor łopatkowy jest układem wylotowym kanału przepływowego sprężarki promieniowej i osiowo-odśrodkowej, w którym następuje zmiana kierunku przepływu z promieniowego na kierunek wyznaczony przez oś komory spalania. $\mathrm{W}$ pracy przedstawiono metodę wyznaczania parametrów strumienia w przekroju wyjściowym układu wylotowego sprężarki promieniowej. Analiza obejmuje układ wylotowy typu osiowego dyfuzora łopatkowego. Zaprezentowano także odpowiednią metodę określania parametrów geometrycznych dla dyfuzora wylotowego tego typu. Wymienione metody mogą być stosowane w trakcie realizacji projektu koncepcyjnego sprężarki, a oparto je na równaniu zachowania energii, równaniu ciągłości przepływu, pierwszej i drugiej zasadzie termodynamiki, równaniu momentu ilości ruchu Eulera oraz funkcjach gazodynamicznych i definicjach używanych w teorii maszyn wirnikowych. Końcowa część pracy zawiera zasady doboru obliczeniowej wartości sprężu sprężarki z promieniowym dyfuzorem łopatkowym oraz wnioski.
\end{abstract}

Słowa kluczowe: sprężarka promieniowa, kanał wylotowy, osiowy dyfuzor łopatkowy

\section{Oznaczenia:}

a - prędkość dźwięku

b - cięciwa

C - prędkość bezwzględna

D - średnica

F - pole powierzchni

$\mathrm{k}$ - wykładnik izentropy

$\mathrm{K}_{\mathrm{m}}$ - współczynnik blokady przekroju

1 - praca właściwa

$\dot{m}$ - strumień masy

M - liczba Macha

n - wykładnik politropy

$\mathrm{p}$ - ciśnienie

$\mathrm{R}$ - indywidualna stała gazowa/promień

\footnotetext{
${ }^{1}$ Autor do korespondencji/corresponding author: Stanisław Antas, Rzeszow University of Technology, 8 Powstańców Warszawy Ave., 35-959 Rzeszów, tel.: (17) 8651501, e-mail: santas@ prz. edu.pl
} 
s - stała w równaniu ciągłości

$\mathrm{t}$ - podziałka

$\mathrm{T}$ - temperatura

$\alpha$ - kąt kierunkowy prędkości bezwzględnej

$\varepsilon$ - funkcja gazodynamiczna gęstości

$\lambda$ - liczba Lavala

$\lambda_{\mathrm{t}}-$ współczynnik tarcia

$\xi$ - współczynnik strat przepływu

$\pi$ - funkcja gazodynamiczna ciśnienia/spręż

$\rho$ - gęstość

$\tau$ - funkcja gazodynamiczna temperatury

$\sigma$ - stopień straty ciśnienia spiętrzenia

q - względna gęstość strumienia masy

Indeksy:

/A - dotyczy parametru części osiowej sprężarki

$/_{\mathrm{R}} \quad$ - dotyczy parametru części promieniowej sprężarki

/s - dotyczy parametru sprężarki

/gr - dotyczy parametru związanego z granicą pracy statecznej

$l_{\mathrm{kr}} \quad-$ dotyczy parametru krytycznego

/o - dotyczy parametru obliczeniowego

/r $\quad$ - dotyczy parametru związanego z tarciem

$I_{\mathrm{zr}} \quad$ - dotyczy parametru zredukowanego

$/ /_{1 \ldots 6}$ - dotyczy parametru związanego z odpowiednim przekrojem kontrolnym

$l^{*} \quad$ - dotyczy parametru spiętrzenia

\section{Wprowadzenie}

Układ wylotowy sprężarki odśrodkowej służy do doprowadzenia sprężonego strumienia powietrza do jego odbiornika. Sprężone powietrze jest zatem kierowane dalej, do kolejnego zespołu silnika w określonym kierunku. Zadaniem układu wylotowego jednostopniowej lub dwustopniowej sprężarki promieniowej jest więc zebranie i odpowiednie skierowanie sprężonego czynnika do odbiorników różnych typów konstrukcyjnych. Wykonanie tego zadania powinno przebiegać w taki sposób, aby praca sprężarki poprzedzającej jej układ wylotowy nie uległa zakłóceniu. W celu zapewnienia prawidłowej pracy sprężarki i odpowiednich osiągów silnika kształty układów wylotowych oraz ich rozwiązania konstrukcyjne należy odpowiednio i starannie dobrać. Trzeba zauważyć, że w przekroju wyjściowym końcowego dyfuzora sprężarki promieniowej prędkość czynnika zwykle znacznie przekracza wartość dopuszczalną, ze względu na prawidłową pracę odbiornika. Układy wylotowe sprężarek promieniowych stanowią zatem dyfuzory o różnych kształtach, w których następuje kontynuacja procesu sprężania powietrza kosztem wyhamowania strumienia. W przypadku lotniczego silnika turbinowego układ ten, łącząc wylot ostatniego dyfuzora sprężarki z dyfuzorem komory spalania, doprowadza powietrze do komory spalania. 
Układ wylotowy w postaci dyfuzora stożkowego sprężarki doładowującej silnik tłokowy doprowadza czynnik do przewodów tłoczących, które są rurami o stałym przekroju, kierującymi strumień powietrza lub mieszankę paliwowo-powietrzną do poszczególnych cylindrów. Do najczęściej stosowanych we współczesnych konstrukcjach układów wylotowych sprężarek promieniowych należą:

- dyfuzor typu łącznika,

- osiowy dyfuzor łopatkowy,

- dyfuzor stożkowy,

- dyfuzor typu kolana,

- dyfuzor zakrzywiony.

Ostatni z wymienionych układów wylotowych jest stosowany wyłącznie $\mathrm{z}$ dyfuzorem rurkowym sprężarki promieniowej lub osiowo-promieniowej $[1,2]$.

Należy zauważyć, że istnieje znaczna liczba publikacji dotyczących analizy parametrów czynnika przepływającego przez wlot, wirnik, dyfuzor bezłopatkowy i łopatkowy sprężarki promieniowej. Należy także zaznaczyć, że w dostępnej literaturze przedmiotu brakuje publikacji dotyczących kompleksowej analizy parametrów termicznych, kinematycznych i geometrycznych układów wylotowych sprężarek promieniowych i osiowo-promieniowych, z wyjątkiem [3, 4].

\section{Osiowy dyfuzor łopatkowy}

Osiowy dyfuzor łopatkowy jest klasycznym rozwiązaniem układu wylotowego sprężarki promieniowej oraz osiowo-promieniowej, a wypływający z niego strumień powinien mieć kierunek zbliżony do kierunku osi silnika [5]. Przykładami zastosowania tego typu konstrukcji układu wylotowego mogą być jednoprzepływowe silniki odrzutowe klasy małego ciągu ze sprężarką promieniową: angielski - NPT301 oraz francuski - Marbore VI. Osiowy dyfuzor łopatkowy jest również stosowany w konstrukcji sprężarek osiowo-odśrodkowych silników śmigłowych: rosyjskiego TWD-10B oraz francuskiego Astazou XX, a także w śmigłowcowym silniku produkcji polskiej - PZL-10W (rys. 1.) i francuskiej Turmo IIIC.

Rys. 1. Turbinowy silnik śmigłowcowy PZL10W; 1 - osiowy dyfuzor łopatkowy

Fig. 1. PZL-10W turboshaft engine; 1 - axial vaned diffuser

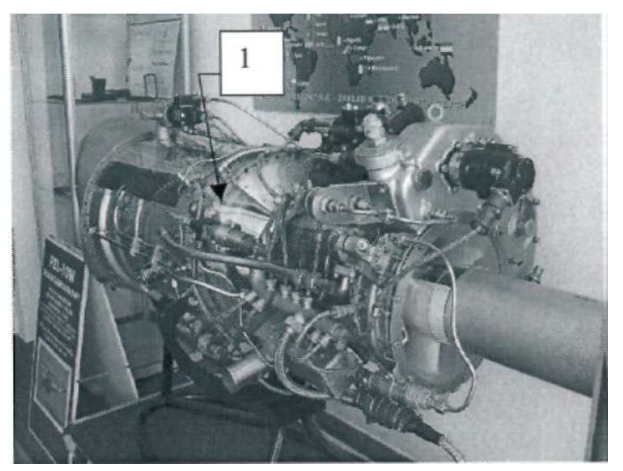


Rysunek 2. przedstawia schemat stopnia sprężarki promieniowej z układem wylotowym typu osiowego dyfuzora łopatkowego z zaznaczonymi charakterystycznymi przekrojami kanału przepływowego. Indeksem 5 oznaczono przekrój wejściowy, a indeksem 6 - przekrój wyjściowy osiowego dyfuzora łopatkowego.

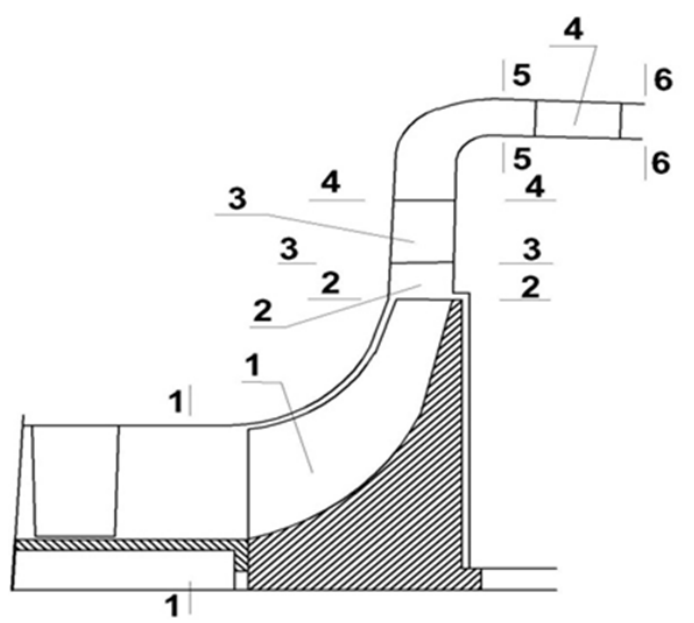

Rys. 2. Schemat stopnia sprężarki promieniowej z układem wylotowym typu osiowego dyfuzora łopatkowego; 1 wirnik, 2 - promieniowy dyfuzor bezłopatkowy, 3 - promieniowy dyfuzor łopatkowy, 4 - osiowy dyfuzor łopatkowy

Fig. 2. Sheme of radial compressor stage with the exhaust system of axial vane diffuser type; 1 - rotor, 2 - radial vaneless diffuser, 3 - radial vaned diffuser, 4 - axial vaned diffuser

Wyznaczanie parametrów termicznych i kinematycznych strumienia oraz parametrów geometrycznych osiowego dyfuzora łopatkowego może przebiegać w przedstawionej dalej kolejności. Temperatura spiętrzenia strumienia w przekroju wejściowym (5-5) oraz wyjściowym (6-6) jest określana z zależności dla przepływu izoenergetycznie odosobnionego w układzie wylotowym sprężarki:

$$
T_{6}{ }^{*}=T_{5}{ }^{*}=T_{4}{ }^{*}
$$

Prędkość krytyczna dźwięku jest obliczana z relacji:

$$
a_{k r 6}=a_{k r 5}=a_{k r 4}=\sqrt{\frac{2 k R}{k+1} T_{4}{ }^{*}}
$$

Liczbę Lavala prędkości strumienia w przekroju wyjściowym:

$$
\lambda_{6}=\frac{C_{6}}{a_{k r 6}}
$$

przyjmuje się według autorów pracy [5] z zakresu $\lambda_{6}=0,15-0,20$.

Prędkość strumienia w przekroju wyjściowym dyfuzora osiowego oblicza się ze wzoru:

$$
C_{6}=\lambda_{6} a_{k r 6}
$$


Otrzymana z relacji (4) wartość prędkości powinna się mieścić w przedziale $C_{6}=80-140 \mathrm{~m} / \mathrm{s}$.

Na podstawie wartości liczby Lavala prędkości strumienia w przekroju wyjściowym można określić wartość funkcji gazodynamicznej temperatury [6]:

$$
\tau\left(\lambda_{6}\right)=\left(1-\frac{k-1}{k+1} \lambda_{6}{ }^{2}\right)
$$

Temperaturę statyczną wyznacza się z zależności definicyjnej funkcji gazodynamicznej temperatury:

$$
T_{6}=T_{6}{ }^{*} \tau\left(\lambda_{6}\right)
$$

Stopień strat ciśnienia spiętrzenia w kanale łukowym, łączącym łopatkowy dyfuzor promieniowy z osiowym oraz w łopatkowym dyfuzorze osiowym wyznacza formuła [7]:

$$
\sigma_{4,6}=1-\frac{k}{k+1} \xi_{4,6}\left(1-\frac{k-1}{k+1} \lambda_{4}{ }^{2}\right)^{\frac{1}{k-1}} \lambda_{4}{ }^{2}
$$

gdzie współczynnik strat przepływu w kanale łukowym łączącym dyfuzor promieniowy $\mathrm{z}$ osiowym oraz $\mathrm{w}$ dyfuzorze osiowym według autora pracy [8] przyjmuje wartości $\xi_{4,6}=0,35-0,42$ dla liczb Lavala na wyjściu z dyfuzora łopatkowego promieniowego $\lambda_{4}=0,39-0,43$.

Wartość ciśnienia spiętrzenia strumienia w przekroju wyjściowym dyfuzora osiowego oblicza się z zależności definicyjnej stopnia strat ciśnienia spiętrzenia:

$$
p_{6}{ }^{*}=\sigma_{4,6} p_{4}{ }^{*}
$$

Po wyznaczeniu wartości funkcji gazodynamicznej ciśnienia strumienia w przekroju wyjściowym osiowego dyfuzora łopatkowego:

$$
\pi\left(\lambda_{6}\right)=\left(1-\frac{k-1}{k+1} \lambda_{6}{ }^{2}\right)^{\frac{k}{k-1}}
$$

możliwe jest obliczenie ciśnienia statycznego strumienia w tym przekroju:

$$
p_{6}=p_{6}{ }^{*} \pi\left(\lambda_{6}\right)
$$

Chcąc otrzymać wartość pola powierzchni kanału przepływowego osiowego dyfuzora łopatkowego w przekroju wyjściowym $F_{6}$, określa się wartość funkcji gazodynamicznej, zwanej względną gęstością strumienia masy:

$$
q\left(\lambda_{6}\right)=\lambda_{6}\left(1-\frac{k-1}{k+1} \lambda_{6}{ }^{2}\right)^{\frac{1}{k-1}}\left(\frac{k+1}{2}\right)^{\frac{1}{k-1}}
$$


Następnie z równania ciągłości uzyskuje się:

$$
F_{6}=\frac{\dot{m} \sqrt{T_{6}{ }^{*}}}{s p_{6}{ }^{*} q\left(\lambda_{6}\right) \sin \alpha_{6} K_{m 6}}
$$

gdzie współczynnik blokady przekroju $K_{m 6}=0,97-0,98$, natomiast kąt wypływu $\mathrm{z}$ dyfuzora osiowego $\alpha_{6}=80-90^{\circ}$ [11].

Funkcję gazodynamiczną gęstości w przekroju wyjściowym (6-6) wyznacza się z formuły:

$$
\varepsilon\left(\lambda_{6}\right)=\left(1-\frac{k-1}{k+1} \lambda_{6}^{2}\right)^{\frac{1}{k-1}}
$$

Po obliczeniu wartości gęstości spiętrzenia strumienia z równania stanu:

$$
\rho_{6}{ }^{*}=\frac{p_{6}{ }^{*}}{R T_{6}{ }^{*}}
$$

określa się wartość gęstości statycznej w przekroju wyjściowym dyfuzora osiowego:

$$
\rho_{6}=\rho_{6}{ }^{*} \varepsilon\left(\lambda_{6}\right)
$$

Sprawdzenie poprawności obliczonych parametrów w przekroju wyjściowym osiowego dyfuzora łopatkowego może przebiegać w następującym porządku:

- temperatura statyczna strumienia

$$
T_{6}=T_{4}+\frac{C_{4}^{2}-C_{6}^{2}}{\frac{2 k R}{k-1}}
$$

- praca sił tarcia podczas przepływu powietrza pomiędzy przekrojem wyjściowym promieniowego dyfuzora łopatkowego (4-4) a wyjściowym osiowego dyfuzora łopatkowego (6-6)

$$
l r_{4,6}=\xi_{4,6} \frac{C_{4}^{2}}{2}
$$

- wykładnik politropy sprężania w układzie wylotowym sprężarki

$$
n_{4,6}=\frac{B}{B-1}
$$

gdzie:

$$
B=\frac{k}{k-1}-\frac{l r_{4,6}}{R\left(T_{6}-T_{4}\right)}
$$


- ciśnienie statyczne strumienia

$$
p_{6}=p_{4}\left(\frac{T_{6}}{T_{4}}\right)^{\frac{n_{4,6}}{n_{4,6}-1}}
$$

- ciśnienie spiętrzenia

$$
p_{6}{ }^{*}=p_{6}\left(\frac{T_{6}{ }^{*}}{T_{6}}\right)^{\frac{k}{k-1}}
$$

- gęstość statyczna

$$
\rho_{6}=\frac{p_{6}}{R T_{6}}
$$

- pole powierzchni kanału przepływowego

$$
F_{6}=\frac{\dot{m}}{C_{6} \rho_{6} K_{m 6}}
$$

Znajomość wartości pola powierzchni kanału przepływowego osiowego dyfuzora łopatkowego w jego przekroju wyjściowym umożliwia określenie średnicy wewnętrznej:

$$
D_{6 W}=\sqrt{D_{6 Z}^{2}-\frac{4 F_{6}}{\pi}}
$$

gdzie wartość średnicy zewnętrznej osiowego dyfuzora łopatkowego w przekroju wyjściowym $D_{6 z}$ przyjmuje się ze względów konstrukcyjnych równą wartości średnicy zewnętrznej dyfuzora wlotowego komory spalania. Średnica średnia osiowego dyfuzora łopatkowego w przekroju wyjściowym jest obliczana $\mathrm{z}$ formuły:

$$
D_{6 s ́ r}=\sqrt{\frac{D_{6 Z}{ }^{2}+D_{6 W} W^{2}}{2}}
$$

Następne zadanie polega na wyznaczeniu parametrów termicznych i kinematycznych strumienia oraz parametrów geometrycznych w przekroju wejściowym osiowego dyfuzora łopatkowego. Ciśnienie spiętrzenia strumienia w przekroju wejściowym osiowego dyfuzora łopatkowego określa się z zależności definicyjnej stopnia strat ciśnienia spiętrzenia:

$$
p_{5}{ }^{*}=\frac{p_{6}{ }^{*}}{\sigma_{5,6}}
$$

gdzie stopień strat ciśnienia spiętrzenia w kanale przepływowym osiowego dyfuzora łopatkowego $\sigma_{5,6}=0,97-0,98[8,9]$. 
Przyjmuje się promień średni kanału przepływowego w przekroju wejściowym osiowego dyfuzora łopatkowego w pierwszym przybliżeniu:

$$
R_{5 s ́ r}=\frac{D_{6 s} r}{2}
$$

Składowa obwodowa prędkości bezwzględnej w przekroju wejściowym osiowego dyfuzora łopatkowego na promieniu średnim jest obliczana przy założeniu stałej cyrkulacji prędkości w kanale łączącym dyfuzor:

$$
c_{5 u}=\frac{c_{4 u} R_{4}}{R_{55 r} r}
$$

Składowa osiowa prędkości bezwzględnej w przekroju wejściowym osiowego dyfuzora łopatkowego na promieniu średnim może być wyznaczana z formuły:

$$
c_{5 a}=c_{6 a}+\Delta c_{a 5,6}
$$

gdzie składowa osiowa prędkości bezwzględnej w przekroju wyjściowym $\mathrm{c}_{6 \mathrm{a}}=$ $=c_{6} \sin \alpha_{6}$, natomiast jej spadek przyjmuje się zwykle z zakresu $\Delta c_{a 5,6}=(5-10) \mathrm{m} / \mathrm{s}$.

Prędkość bezwzględna w przekroju wejściowym osiowego dyfuzora bezłopatkowego oraz jej kąt kierunkowy na promieniu średnim są określane z trójkąta prędkości:

$$
\begin{aligned}
& c_{5}=\sqrt{c_{5 a}^{2}+c_{5 u}^{2}} \\
& \alpha_{5}=\operatorname{arctg} \frac{c_{5 a}}{c_{5 u}}
\end{aligned}
$$

Liczba Lavala prędkości bezwzględnej strumienia w przekroju wejściowym osiowego dyfuzora łopatkowego jest określana z zależności:

$$
\lambda_{5}=\frac{c_{5}}{a_{k r 5}}
$$

Funkcja gazodynamiczna - względna gęstość strumienia masy jest wyznaczana z relacji:

$$
q\left(\lambda_{5}\right)=\lambda_{5}\left(1-\frac{k-1}{k+1} \lambda_{5}^{2}\right)^{\frac{1}{k-1}}\left(\frac{k+1}{2}\right)^{\frac{1}{k-1}}
$$

Pole powierzchni osiowego dyfuzora łopatkowego w przekroju wejściowym oblicza się, opierając się na równaniu ciągłości:

$$
F_{5}=\frac{\dot{m} \sqrt{T_{5}^{*}}}{s p_{5}^{*} q\left(\lambda_{5}\right) \sin \alpha_{5} K_{m 5}}
$$

gdzie współczynnik blokady przekroju $K_{m 5}=0,97-0,98$ [9]. 
Na podstawie znanej wartości pola powierzchni $F_{5}$ jest określana średnica wewnętrzna:

$$
D_{5 w}=\sqrt{D_{5 s ́ r}^{2}-\frac{2 F_{5}}{\pi}}
$$

oraz zewnętrzna:

$$
D_{5 z}=\sqrt{\frac{4 F_{5}}{\pi}+D_{5 w}^{2}}
$$

osiowego dyfuzora łopatkowego w jego przekroju wejściowym.

Należy zauważyć, że w przypadku osiowego dyfuzora łopatkowego ze stałą średnicą zewnętrzną: $D_{5 z}=D_{6 z}=$ idem, po obliczeniu pola powierzchni $F_{5}$ ze wzoru (34) wyznacza się wartość średnicy średniej oraz promienia średniego kanału przepływowego w jego przekroju wejściowym:

$$
\begin{aligned}
& D_{5 s ́ r}=\sqrt{D_{5 z}^{2}-\frac{2 F_{5}}{\pi}} \\
& R_{5 s ́ r}=\frac{D_{5 s \dot{s}}}{2}
\end{aligned}
$$

a następnie sprawdza się dokładność wyznaczonej wartości promienia średniego:

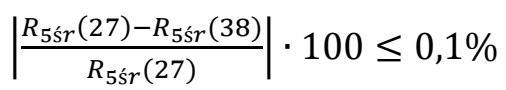

Jeżeli relacja (39) jest spełniona, wówczas obliczenia można kontynuować. Przy braku jej spełnienia do obliczenia wartości składowej obwodowej na promieniu średnim $c_{5 u}$ (wzór (28)) podstawia się wartość promienia średniego (wzór (38)) i wykonuje drugie przybliżenie, przy czym dla kolejnych przybliżeń $j$ oraz j+1 określona zależnością (38) wartość powinna spełniać warunek:

$$
\left|\frac{R_{5 s r}^{j}(38)-R_{5 s r}^{j+1}(38)}{R_{5 s r}^{j}(38)}\right| \cdot 100 \leq 0,1 \%
$$

Względna wartość średnicy wewnętrznej na wejściu i wyjściu osiowego dyfuzora łopatkowego jest wyznaczana z zależności:

$$
\begin{aligned}
& \overline{d_{5 w}}=\frac{D_{5 w}}{D_{5 z}} \\
& \overline{d_{6 w}}=\frac{D_{6 w}}{D_{6 z}}
\end{aligned}
$$


Wysokość łopatek w przekroju wejściowym i wyjściowym osiowego dyfuzora łopatkowego określają relacje:

$$
\begin{aligned}
& h_{5}=\frac{D_{5 z}-D_{5 w}}{2} \\
& h_{6}=\frac{D_{6 z}-D_{6 w}}{2}
\end{aligned}
$$

Kąt skręcenia strumienia w palisadzie osiowego dyfuzora łopatkowego oblicza się z formuły definicyjnej tego kąta:

$$
\Delta \alpha_{6,5}=\alpha_{6}-\alpha_{5}
$$

Potrzebną gęstość palisady osiowego dyfuzora łopatkowego wyznacza się analogicznie do obliczania palisady wieńca dyfuzora stopnia osiowego sprężarki, wykorzystując wykresy przedstawione na rys. 3. i 4.

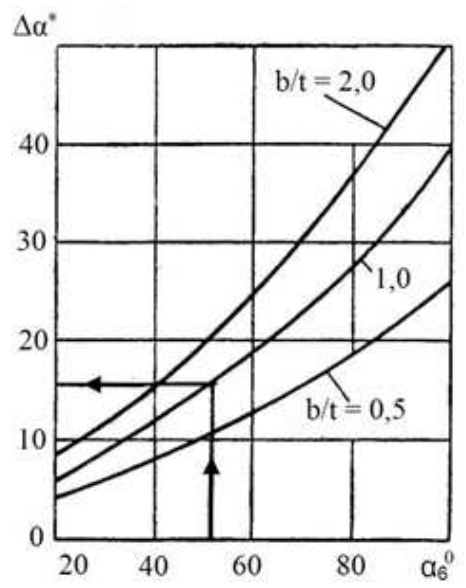

Rys. 3. Główna charakterystyka zakresów nominalnych palisady $[10,11]$

Fig. 3. Cascade nominal deflection angle versus air outlet angle $[10,11]$

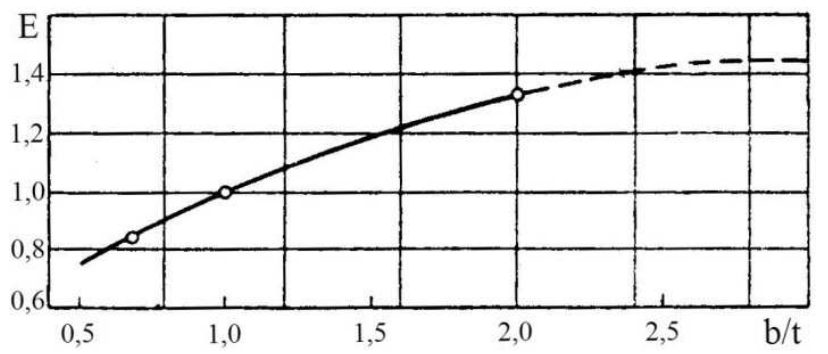

Rys. 4. Zmiana wartości względnej nominalnego kąta skręcenia w palisadzie przy zmianie gęstości palisady [9]

Fig. 4. Change of the relative value of cascade nominal deflection angle versus palisade solidity [9] 
Z rysunku 3. określa się, zgodnie z wartością kąta $\alpha_{6}$, nominalną wartość kąta skręcenia w palisadzie $\Delta \alpha^{*}=\Delta \alpha_{b / t=1}$ dla gęstości palisady $b / t=1$, a następnie według stosunku $E=\frac{\Delta \alpha_{6,5}}{\Delta \alpha_{b / t=1}}$ z rys. 4 . wyznacza się potrzebną gęstość palisady na promieniu średnim $(b / t)_{p s s}$. Znając potrzebną gęstość palisady na promieniu średnim, oblicza się potrzebną gęstość palisady u podstawy łopatek:

$$
\left(\frac{b}{t}\right)_{p w}=\overline{d_{6 w}}\left(\frac{b}{t}\right)_{p s ́ r}
$$

Cięciwę profilu łopatki wieńca osiowego dyfuzora łopatkowego określa relacja:

$$
b=\frac{D_{6 z}-D_{6 w}}{2 \bar{h}}
$$

gdzie wartości wydłużenia łopatek osiowego dyfuzora łopatkowego przyjmuje się z zakresu $\bar{h}=0,20-0,25$ [5].

Podziałka palisady łopatek osiowego dyfuzora łopatkowego na promieniu wewnętrznym jest obliczana z zależności:

$$
t_{6 w}=\frac{b}{\left(\frac{b}{t}\right)_{p w}}
$$

Liczbę łopatek wieńca osiowego dyfuzora łopatkowego wyznacza się z formuły:

$$
z_{O D}=\frac{\pi D_{6 w}}{t_{6 w}}
$$

Otrzymaną liczbę łopatek zaokrągla się do liczby całkowitej, tzn. wyznacza się rzeczywistą, czyli skorygowaną liczbę łopatek osiowego dyfuzora $\left(z_{O D}\right)_{r z}$, a następnie koryguje się wartość podziałki i gęstości palisady. Rzeczywista wartość podziałki palisady osiowego dyfuzora łopatkowego na średnicy wewnętrznej jest obliczana ze związku:

$$
\left(t_{6 w}\right)_{r z}=\frac{\pi D_{6 w}}{\left(z_{O D}\right)_{r z}}
$$

Ze względów technologicznych zaleca się spełnienie zależności: $\left(t_{6 w}\right)_{r z} \geq 12$ $\mathrm{mm}$. Określenie rzeczywistej wartości podziałki palisady $\left(t_{6 w}\right)_{r z}$ umożliwia wyznaczenie rzeczywistej gęstości palisady osiowego dyfuzora łopatkowego:

$$
\left(\frac{b}{t}\right)_{w r z}=\frac{b}{\left(t_{6 w}\right)_{r z}}
$$

gdyż $b_{w}=b_{z}=b=$ idem. 
Zaleca się spełnienie relacji: $\left(\frac{b}{t}\right)_{w r z} \leq 1,8-2,0$ oraz uzyskanie wartości gęstości palisady osiowego dyfuzora łopatkowego na promieniu średnim dla silników odrzutowych $\left(\frac{b}{t}\right)_{s ́ r}=1,5-1,9$, natomiast dla silników śmigłowych i śmigłow$\operatorname{cowych}\left(\frac{b}{t}\right)_{\dot{s} r}=1,35-1,8$. Ważnym zagadnieniem konstrukcyjnym jest także prawidłowe zaprofilowanie przebiegu łukowego kanału łączącego promieniowy dyfuzor łopatkowy z osiowym dyfuzorem łopatkowym. Straty ciśnienia spiętrzenia związane ze zmianą kierunku przepływu ogranicza się przez zwiększenie promienia zagięcia kanału łączącego, umieszczonego pomiędzy dyfuzorem promieniowym a dyfuzorem osiowym. Wpływa to na wzrost sprawności zespołu, lecz jednocześnie prowadzi do zwiększenia średnicy zewnętrznej układu wylotowego sprężarki. Kształtując odpowiednio profil ścianki wewnętrznej i zewnętrznej kanału łączącego dyfuzory, otrzymuje się układ wylotowy o niskim współczynniku strat. Promień łuku wewnętrznej ścianki kanału łączącego dyfuzory (rys. 5.) wyznacza się na podstawie parametru zagięcia [12]:

$$
B_{p}=\frac{R_{5 w}-R_{4}}{h_{d}}
$$

gdzie: $R_{5 w}$ - promień łuku wewnętrznej ścianki kanału łączącego dyfuzory na wylocie (promień wewnętrznej ścianki osiowego dyfuzora łopatkowego w przekroju wejściowym), $R_{4}$ - promień zewnętrzny (wylotu) promieniowego dyfuzora łopatkowego, $h_{d}$ - rozpiętość promieniowego dyfuzora łopatkowego wyznaczana z relacji:

$$
h_{d}=R_{4}-R_{3}
$$

W formule (53) przez $R_{3}$ oznaczono promień wewnętrzny (wlotu) promieniowego dyfuzora łopatkowego.

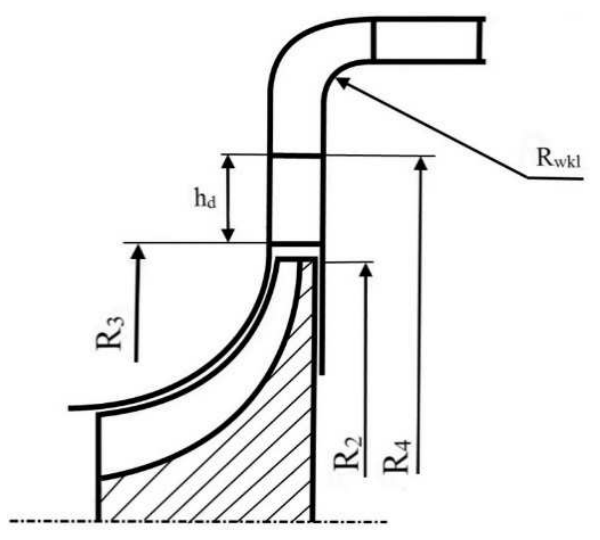

Rys. 5. Schemat układu wylotowego typu osiowego dyfuzora łopatkowego sprężarki promieniowej z oznaczeniem charakterystycznych promieni

Fig. 5. Scheme of radial compressor with exhaust system of axial vaned diffuser type with designation of characteristic radiuses 
Według autorów pracy [12] wartość parametru zagięcia kanału łączącego dyfuzory powinna się zawierać w przedziale $B_{p}=0,4-1,5$. Niższe wartości parametru zagięcia dotyczą sprężarek lotniczych silników turbinowych, wyższe zaś sprężarek przemysłowych oraz sprężarek silników okrętowych i trakcyjnych.

W konstrukcjach sprężarek promieniowych i osiowo-promieniowych silników lotniczych wszystkich typów szczególną uwagę poświęca się gabarytom i masie tej maszyny wirnikowej. Mając na względzie wysokie wartości ciągu czołowego oraz niskie wartości masy sprężarki wirnikowej, opierając się na rezultatach badań eksperymentalnych dyfuzorów bezłopatkowych i łopatkowych, przyjmuje się następujące wartości stosunków charakteryzujących średnie: $D_{3} / D_{2}=1,05-1,15$ oraz $D_{4} / D_{3}=1,25-1,35$ [7]. Według autorów pracy [12] dla sprężarek promieniowych i osiowo-promieniowych odrzutowych silników jednoprzepływowych i dwuprzepływowych zaleca się przyjmować wartości ilorazu średnic: $D_{4} / D_{2}=1,3-1,5$.

W przypadku ilorazu średnicy gabarytowej sprężarki do średnicy wylotu wirnika $D_{6 z} / D_{2}>1,4$ zasadnicza część sprężenia czynnika przebiega w promieniowym dyfuzorze łopatkowym, a osiągane wartości liczby Lavala na wejściu osiowego dyfuzora łopatkowego są nieznaczne i zawierają się $\mathrm{w}$ przedziale $\lambda_{5}=0,3-0,4$ [5]. Dla takich wartości liczb Lavala łopatki dyfuzora osiowego wykonuje się o stałej grubości, a ich promień krawędzi natarcia i spływu jest równy połowie grubości profilu, natomiast linia szkieletowa stanowi łuk koła. Przy ilorazie $D_{6 z} / D_{2} \leq 1,35$ rola osiowego dyfuzora łopatkowego w sprężaniu wzrasta, a jego łopatki stanowią profile sprężarkowe. Rosną też wartości liczby Lavala w jego przekroju wejściowym $\lambda_{5}=0,5-0,6$. Niekiedy, ze względów technologicznych, wykonuje się osiowy dyfuzor łopatkowy ze stałymi średnicami kanału przepływowego na jego wlocie i wylocie.

\section{Uwagi końcowe}

Obliczeniowa wartość sprężu zarówno sprężarki promieniowej, jak i osiowo-promieniowej $\pi_{S o}^{*}$ powinna być większa od wartości sprężu sprężarki $\pi_{S}^{*}$ zadanej w obliczeniach termogazodynamicznych silnika, a odpowiadającej wartości tego parametru na linii współpracy sprężarki i turbiny.

W lotniczym silniku turbinowym sprężarka bezpośrednio współpracuje z zasilanym przez nią całym kanałem przepływowym silnika, stanowiącym układ dławiący (przepustnicę na wylocie ze sprężarki). W układzie silnika wartość sprężu sprężarki $\pi_{S}^{*}$ określa się zwykle podczas prób odbiorczych, mierząc jego wartość na linii współpracy sprężarki z napędzającą sprężarkę turbiną. 


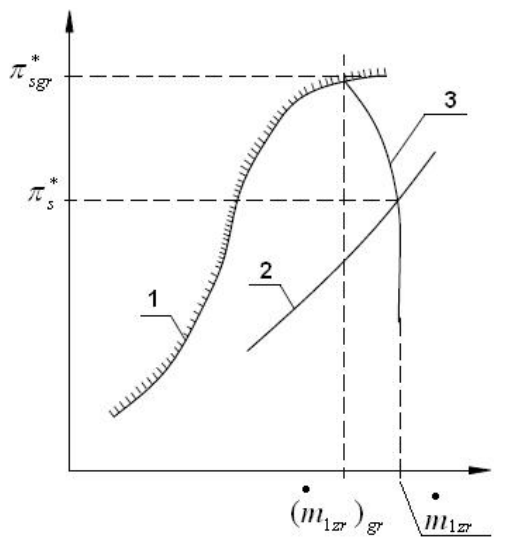

Rys. 6. Ilustracja określenia zapasu statecznej pracy sprężarki; 1 - granica pracy statecznej, 2 - linia współpracy S-TS, 3 - krzywa dławienia $n_{S z r}=$ idem

Fig. 6. Illustration of determination for surge margin compressor; 1 - surge line, 2 - working line S-TS, 3 corrected speed of impeller $n_{S z r}=$ idem

Ilościową ocenę odległości linii współpracy S-TS od granicy statecznej pracy sprężarki (rys. 6.) umożliwia zapas statecznej pracy sprężarki, zdefiniowany wyrażeniem [13]:

$$
\Delta K s=\frac{\pi_{S g r}^{*} /\left(\dot{m}_{1 z r}\right)_{g r}-\pi_{S}^{*} / \dot{m}_{1 z r}}{\pi_{S}^{*} / \dot{m}_{1 z r}}
$$

gdzie: $\dot{m}_{1 z r}$ i $\left(\dot{m}_{1 z r}\right)_{g r}$ - odpowiednio zredukowany strumień masy powietrza, określony na wlocie do sprężarki w punkcie współpracy i na granicy statecznej pracy przy $n_{S z r}=$ idem, natomiast: $\pi_{S}^{*}$ i $\pi_{S g r}^{*}$ - odpowiednio spręż sprężarki na linii współpracy S-TS i na granicy statecznej pracy przy $n_{S z r}=$ idem.

W zależności od typu konstrukcyjnego sprężarki, sposobu regulacji i zastosowania silnika zapas statecznej pracy wynosi zwykle: $\Delta K s=0,1-0,2-\mathrm{w}$ przypadku sprężarek promieniowych oraz $\Delta K s=0,15-0,25 \mathrm{w}$ przypadku osiowych [5].

Badania eksperymentalne sprężarek promieniowych z promieniowymi dyfuzorami łopatkowymi wykazały silny wpływ liczby Macha prędkości strumienia w przekroju wejściowym, tj. gardzieli dyfuzora łopatkowego $M_{3}$, na przebieg krzywej dławienia sprężarki. Przebieg krzywej dławienia sprężarki promieniowej dla wybranej, obliczeniowej prędkości obrotowej charakteryzuje minimalna wartość strumienia masy powietrza w przekroju wejściowym sprężarki $\left(\dot{m}_{1 \min }\right)=\left(\dot{m}_{1 z r}\right)_{g r}, \quad$ odpowiadająca maksymalnej wartości jej sprężu
$\pi_{S \max }^{*}=\pi_{S g r}^{*}$ oraz maksymalna wartość strumienia masy powietrza w przekroju 
wejściowym sprężarki $\dot{m}_{1 \max }=\dot{m}_{1 z r}$, stanowiące odciętą pionowego odcinka charakterystyki, którego rzędna w najwyższym punkcie odpowiada sprężowi $\pi_{S}^{*}$ na linii współpracy S-TS [5]. Zaczerpnięty z pracy [5] rys. 7. ilustruje zależność $\dot{m}_{1 \max }-\dot{m}_{1 \min } / \dot{m}_{1 \min }=f\left(M_{3}\right)$, uzyskaną na podstawie rezultatów badań eksperymentalnych wielu sprężarek ośrodkowych zawierających promieniowy dyfuzor łopatkowy.

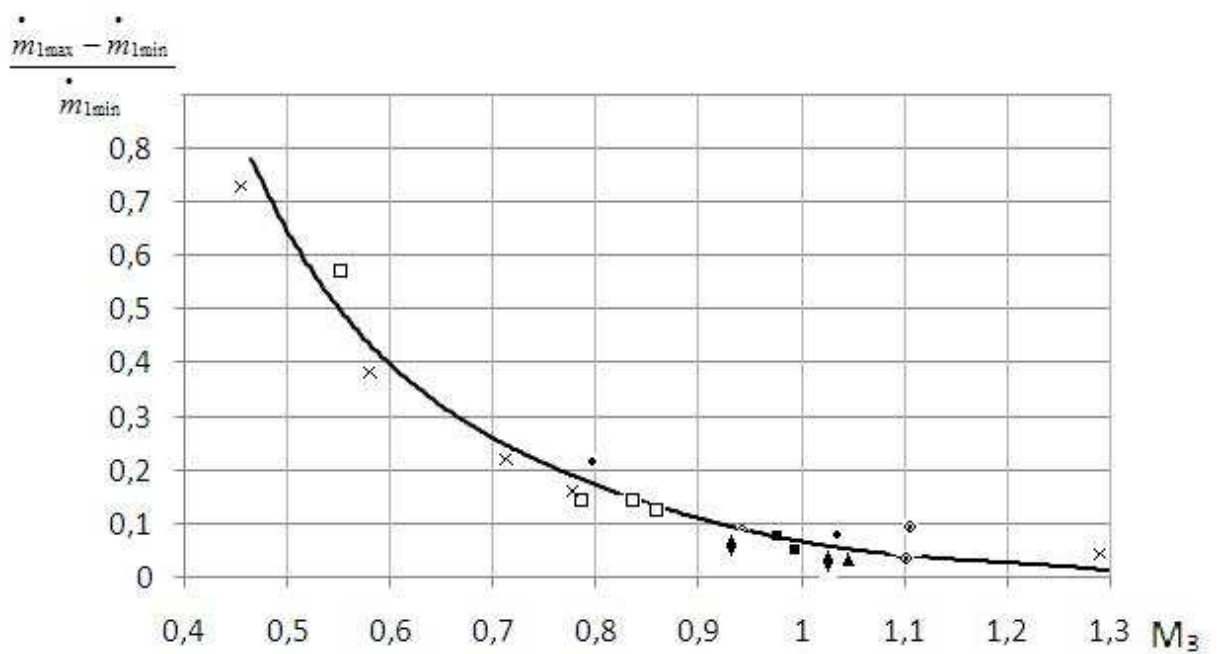

Rys. 7. Zależność ilorazu $\left(\dot{m}_{1 \max }-\dot{m}_{1 \min }\right) / \dot{m}_{1 \min }$ od liczby Macha $M_{3}$ w przekroju wejściowym promieniowego dyfuzora łopatkowego

Fig. 7. Dependence of quotient $\left(\dot{m}_{1 \max }-\dot{m}_{1 \min }\right) / \dot{m}_{1 \min }$ versus Mach numer $M_{3}$ at entrance section of radial vaned diffuser

$\mathrm{Z}$ rysunku 7. wynika bezpośrednio, że ze wzrostem liczby Macha $M_{3}$ maleje wartość parametru $\left(\dot{m}_{1 \max }-\dot{m}_{1 \min }\right) / \dot{m}_{1 \min }$, a dla $M_{3}>1,2$ krzywa dławienia przebiega niemal pionowo. Analogiczną zależność, typu $\frac{\left(\dot{m}_{1 \max }-\dot{m}_{1 \min }\right)}{\dot{m}_{1 \max }}=f\left(\pi_{S}^{*}\right)$ podaje Japikse w pracy [14]. Przy uwzględnieniu tego, spręż obliczeniowy, na którego wartość projektuje się sprężarkę promieniową, powinien zapewniać jej pracę z zadowalającą wartością zapasu statecznej pracy, zatem $\pi_{S g r}^{*}=\pi_{S o}^{*}$ i relację (54) można także zapisać w następującej postaci:

$$
\Delta K s=\frac{\pi_{S o}^{*} / \dot{m}_{1 \min }-\pi_{S}^{*} / \dot{m}_{1 \max }}{\pi_{S}{ }^{*} / \dot{m}_{1 \max }}
$$


skąd obliczeniowa wartość sprężu sprężarki promieniowej:

$$
\pi_{S o}^{*}=\frac{(1+\Delta K s) \pi_{S}{ }^{*}}{1+\left(\dot{m}_{1 \max }-\dot{m}_{1 \min }\right) / \dot{m}_{1 \min }}
$$

lub

$$
\pi_{S o}^{*}=\frac{(1+\Delta K s) \pi_{S}{ }^{*}}{1+\bar{m}}
$$

gdzie

$$
\bar{m}=\frac{\dot{m}_{1 \max }-\dot{m}_{1 \min }}{\dot{m}_{1 \min }}
$$

Obliczeniowa wartość sprężu sprężarki promieniowej jest wyznaczana ze wzorów (56) lub (57), po przyjęciu wartości jej zapasu statecznej pracy $\Delta K s$ liczby Macha $M_{3}$ oraz określeniu parametru $\bar{m}$ (rys. 7.). Na wartość liczby Macha $M_{3}$ istotny wpływ wywiera stosunek średnicy wyjściowej $D_{3}$ do wejściowej $D_{2}$ dyfuzora bezłopatkowego. We współczesnych konstrukcjach sprężarek promieniowych lotniczych silników turbinowych stosunek średnic zwykle zawiera się w przedziale wartości $D_{3} / D_{2}=1,05-1,10$ [10]. Przedstawioną na rys. 7. zależność można wykorzystać dla doboru odpowiedniej wartości tego stosunku średnic. Według pracy [5] w przypadku $M_{3}<1,2$ dla wyboru stosunku średnic $D_{3} / D_{2}$ odpowiadającego wybranej wartości liczby Macha $M_{3}$ można wykorzystać przybliżoną zależność:

$$
\frac{D_{3}}{D_{2}}=\frac{-}{1+a^{\prime}(\bar{M}-1)}
$$

gdzie:

$$
\bar{M}=\sqrt{\frac{\frac{1}{M_{3}^{2}}+0,2}{\frac{1}{M_{2}^{2}}+0,2}}
$$




$$
a^{\prime}=\frac{\lambda_{t} D_{2}}{8 \operatorname{tg} \alpha_{2} b_{2}}
$$

W przedstawionych relacjach oznaczono przez:

$D_{2}$ - średnicę wirnika na wylocie,

$b_{2}$ - szerokość kanału wylotowego wirnika (wysokość łopatek),

$\alpha_{2}$ - kąt kierunkowy prędkości bezwzględnej w przekroju wyjściowym wirnika,

$\lambda_{t}-$ współczynnik tarcia $\left(\lambda_{t}=0,03\right)$,

$M_{2}$ - liczbę Macha prędkości bezwzględnej w przekroju wyjściowym wirnika.

Z kolei według R.H. Aungiera [15]:

$$
\frac{D_{3}}{D_{2}}=1+\alpha_{3} / 360+M_{2}^{2} / 15
$$

gdzie $\alpha_{3}$ - kąt kierunkowy prędkości bezwzględnej w przekroju wyjściowym dyfuzora bezłopatkowego.

Sprężarka osiowo-odśrodkowa jest najkorzystniejszym wariantem dla śmigłowych i śmigłowcowych silników turbinowych o małych strumieniach masy powietrza $\dot{m}=2-6 \mathrm{~kg} / \mathrm{s}$ i umiarkowanych sprężach $6 \leq \pi_{s}^{*} \leq 12$. W sprężarce osiowej, przy wspomnianych wydatkach i sprężach, łopatki końcowych stopni są zbyt krótkie, co wpływa ujemnie na wartość jej sprawności izentropowej. Szczegółową procedurę rozdziału sprężu sprężarki osiowo-promieniowej $\pi_{S}^{*}$ pomiędzy część osiową $\pi_{S A}^{*}$ i odśrodkową $\pi_{S R}^{*}$ podano w pracy [16]. Ponieważ spręż sprężarki osiowo-odśrodkowej jest iloczynem spręży jej części składowych:

$$
\pi_{S}^{*}=\pi_{S A}^{*} \pi_{S R}^{*}
$$

to obliczeniową wartość sprężu sprężarki osiowo-promieniowej określa relacja:

$$
\pi_{S o}^{*}=\left(\pi_{S A}^{*}\right)_{o}\left(\pi_{S R}^{*}\right)_{o}
$$

gdzie obliczeniowa wartość sprężu części osiowej sprężarki jest wyznaczana analogicznie do sprężarki osiowej:

$$
\left(\pi_{S A}^{*}\right)_{o}=\pi_{S A}^{*}\left(1+\frac{\pi_{S A}^{*}}{100}\right)
$$


Obliczeniowa wartość sprężu części promieniowej sprężarki osiowo-odśrodkowej $\left(\pi_{S R}^{*}\right)_{o}$ może być obliczana z formuły (56) lub (57).

Obliczenia układu wylotowego, a zarazem obliczenia przepływowe sprężarki promieniowej lub osiowo-promieniowej, można uważać za poprawne, jeśli w rezultacie obliczeń uzyskano rzeczywistą wartość sprężu obliczeniowego sprężarki, definiowanego jako stosunek ciśnienia spiętrzenia w przekroju wyjściowym układu wylotowego $p_{w y l}^{*}$ do ciśnienia spiętrzenia w przekroju wejściowym sprężarki $p_{1}^{*}$ :

$$
\left(\pi_{S o}^{*}\right)_{r z}=\frac{p_{w y l}^{*}}{p_{1}^{*}}
$$

zbliżoną do wartości teoretycznej (wzory (56) lub (57) oraz (64)). Zaleca się, aby błąd względny wartości wymienionych spręży nie przekroczył dla projektu wstępnego $1 \%$ [7], a dla projektu koncepcyjnego $5 \%$ [8, 17].

Jeżeli błąd względny rzeczywistej wartości sprężu obliczeniowego (wzór (66)) oraz wartości teoretycznej na początku obliczeń przepływowych sprężarki (formuły (56) lub (57) oraz (64)) przekracza wartość dopuszczalną, to obliczenia sprężarki należy powtórzyć, przyjmując inną wartość sprawności hydraulicznej mniejszą przy $\left(\pi_{S}^{*}\right)_{o r z}<\pi_{S o}^{*}$ i większą, gdy $\left(\pi_{S o}^{*}\right)_{r z}>\pi_{S o}^{*}$. Zagadnienie doboru obliczeniowej wartości sprężu sprężarki promieniowej i osiowo-odśrodkowej w przypadku zastosowania dyfuzora rurkowego przedstawiono szczegółowo w pracy [3].

\section{Wnioski}

W oryginalnej metodzie analizy parametrów termicznych, kinematycznych oraz geometrycznych układu wylotowego typu osiowego dyfuzora łopatkowego wykorzystano równania zachowania energii, masy i momentu pędu oraz definicje stosowane w teorii maszyn wirnikowych w odniesieniu do przepływu jednowymiarowego przez ten zespół. Metodę zaleca się stosować podczas realizacji projektu koncepcyjnego sprężarki. Osobnym, ważnym zagadnieniem do rozwiązania w trakcie prowadzenia projektu koncepcyjnego sprężarki promieniowej i osiowo-promieniowej z promieniowym dyfuzorem łopatkowym jest odpowiedni wybór jej sprężu obliczeniowego. Podane w pracy relacje (56) i (57) umożliwiają racjonalne określenie wartości sprężu obliczeniowego sprężarki odśrodkowej z promieniowym dyfuzorem łopatkowym, natomiast relacje (64) oraz (65) - wyznaczenie tego parametru dla sprężarki osiowo-odśrodkowej. Niniejszy artykuł jest pierwszą na świecie publikacją dotyczącą zagadnień projektu koncepcyjnego osiowego dyfuzora łopatkowego. 


\title{
Literatura
}

[1] Antas S.: Dyfuzor rurkowy sprężarki promieniowej i osiowo-promieniowej, ZN PRz, Mechanika, 30 (2013) 213-228.

[2] Antas S.: Pipe diffuser for radial and axial - centrifugal compressors, Int. J. Turbo Jet Engines, 31 (2014) 29-36.

[3] Antas S.: Dyfuzor zakrzywiony (o kontrolowanym zarysie), ZN PRz, Mechanika, 30 (2013) 353-373.

[4] Antas S.: Układ wylotowy typu łącznika sprężarki promieniowej, ZN PRz, Mechanika, 30 (2013) 95-107.

[5] Dmitriewskij W.I.: Gazodynamiczeskij rasczot i profilirowanie stupieni centrobieżnogo kopriessora, Techniczeskij otczet, No. 137 CIAM, Moskwa 1960.

[6] Antas S., Lesikiewicz A.: Teoria silników przepływowych. Funkcje gazodynamiczne, OW PRz, Rzeszów 1987.

[7] Biełousow A.N., Musatkin N.F., Radko W.M.: Teorija i rasczot awiacionnych łopatocznych maszyn, Samarskij Gosudarstwiennyj Aerokosmiczeskij Institut, Samara 2003.

[8] Kenny D.P.: A novel low-cost diffuser for high-performance centrifugal compressors, J. Eng. Power, 91 (1969) 37-47.

[9] Cholscewnikov K.W.: Teoria i rasczot awiacyonnych łopatocznych maszin, Maszinostrojenie, Moskwa 1970.

[10] Dżygadło Z. i in.: Zespoły wirnikowe silników turbinowych, WKiŁ, Warszawa 1982.

[11] Podobujew Ju. S., Sielezniew K.P.: Teorija i rasczot osiewych i centrobieżnych kompriessorow, Maszgiz, Moskwa 1957.

[12] Walsh P.P., Fletcher P.: Gas Turbine Performance. Second Edition, Blackwell Science Ltd., Oxford 2004.

[13] Antas S.: Ocena wpływu wybranych metod modyfikacji maszyn wirnikowych turbinowych silników śmigłowych i śmigłowcowych na zapas statecznej pracy sprężarki, OW PRz, Rzeszów 2006.

[14] Japikse D.: Decisive factors in advanced centrifugal compressor design and development, Concepts ETI, Inc. Wilder, Vermont 2006.

[15] Aungier R.H.: Centrifugal compressors. A. Strategy for Aerodynamic Design and Analysis, ASME Press., New York 2000.

[16] Antas S., Wolański P.: Obliczenia termogazodynamiczne lotniczych silników turbinowych, Wydawnictwa Politechniki Warszawskiej, Warszawa 1989.

[17] Stieczkin B.S.: Tieorija rieaktiwnych dwigatielej. Vol. 2, Łopatocznyje maszyny, Oborongiz, Moskwa 1956.

\section{THE DOWNSTREAM SYSTEM OF VANED AXIAL DIFFUSER TYPE FOR RADIAL COMPRESSOR}

\author{
Abstract \\ The vaned axial diffuser is the exhaust system of the centrifugal or axial-centrifugal compres- \\ sor flow channel where the change of flow direction takes place from radial direction to the direction
}


defined by the axis of the combustion chamber. The paper presents a method for determining flow parameters at the outlet section downstream duct of a radial or axial-radial compressor. The analysis includes the exhaust system in the form of vaned axial diffuser type (straightening vanes, de-swirl cascade). The suitable method of determining geometrical parameters for this exhaust diffuser is also presented there. The mentioned method (for conceptual design of compressor) is based on the equation of energy conservation, equation of continuity, first and second law of thermodynamics, Euler's moment of momentum equation, gas dynamics functions and definitions used in the theory of turbo-machines. The final part of the article includes principles for selection of computational value pressure ratio for the compressor with radial vaned diffuser and conclusions.

Keywords: radial compressor, exhaust duct, vaned axial diffuser

DOI: $10.7862 / \mathrm{rm} .2018 .10$

Przestano do redakcji: 23.03.2018

Przyjęto do druku: 20.04.2018 